\title{
UM ESTUDO EXPLORATÓRIO SOBRE A INDÚSTRIA BRASILEIRA DE ANIMAÇÃO PARA A TV
}

\author{
Wilian Gatti Junior \\ gatti.wilian@gmail.com \\ Universidade Anhembi Morumbi - São Paulo, SP / Brasil \\ Marilson Alves Gonçalves \\ (in memoriam) \\ Ana Paula Franco Paes Leme Barbosa \\ afleme@gmail.com \\ Universidade de São Paulo - São Paulo, SP / Brasil
}

http://dx.doi.org/10.1590/1413-2311057201238250

Recebido em 25/09/2012

Aprovado em 23/10/2013

Disponibilizado em 01/08/2014

Avaliado pelo sistema double blind review

Revista Eletrônica de Administração

Editor: Luís Felipe Nascimento

ISSN 1413-2311 (versão on-line)

Editada pela Escola de Administração da Universidade Federal do Rio Grande do Sul.

Periodicidade: Quadrimestral

Sistema requerido: Adobe Acrobat Reader.

\section{RESUMO}

A economia criativa tem recebido pouca atenção da comunidade acadêmica, a despeito de sua importância econômica e cultural. Este artigo procura contribuir com a literatura sobre o tema com foco na indústria de animação, mais precisamente na produção de animações para a TV, pois recentemente o país produziu animações de sucesso na TV paga exibidas não só no Brasil, mas também em vários países. Este artigo procura analisar como as produtoras nacionais construíram vantagens competitivas que as possibilitaram obter êxito em suas produções em um mercado dominado por estúdios internacionais. Para atingir esse propósito foi conduzida uma pesquisa exploratório-descritiva analisando três produtoras (Flamma, TV PinGuim e 2DLab) que exibem seu produto no canal Discovery Kids, voltado ao público préescolar. Foram entrevistados todos os sócios das produtoras (em um total de seis, dois de cada produtora), mais uma representante da indústria de animação para o cinema. Além das entrevistas, foram utilizados dados secundários, basicamente coletados na mídia (jornais, revistas e internet). $\mathrm{O}$ trabalho revelou a convergência de duas fontes de vantagens competitivas. A primeira ligada a fatores internos às produtoras estudadas (conhecimento técnico e visão do negócio) e a segunda fonte ligada a fatores ambientais, criados pela cadeia produtiva dessa indústria (criação de novos canais de TV, interesse de parceiros internacionais e linhas de financiamento para a produção).

Palavras-Chave: Indústria de animação; Indústria criativa; Produção para TV; Competitividade; Criatividade.

REAd | Porto Alegre - Edição 78 - № 2 - maio/agosto 2014 - p. 461-495 
Um estudo exploratório sobre a indústria brasileira de animação para a TV

\title{
AN EXPLORATORY STUDY ON THE BRAZILIAN ANIMATION INDUSTRY FOR
}

\section{TV}

\begin{abstract}
The creative economy has received little attention from the academic community, despite its economic and cultural importance. This article seeks to contribute to the literature on the subject focusing on the animation industry, specifically the TV animation production, because recently the country produced success animations series on cable TV broadcasted not only in Brazil but also in several countries. This paper analyzes how the national producers built competitive advantages that allowed succeeding in their productions in a market dominated by international studios. To achieve this aim we conducted an exploratory descriptive research analyzing three producers (Flamma, TV PinGuim and 2DLab) that display your product in the Discovery Kids channel that focus on preschool shows. We interviewed all producers (in a total of six, two from each producer), plus a representative of the animation industry for the cinema. Besides the interviews, we used secondary data, collected primarily in the media (newspapers, magazines and internet). The study revealed the convergence of two sources of competitive advantage. The first related to internal factors to producing studied (technical knowledge and business vision) and the second source connected to environmental factors created by the industry production chain (creation of new TV channels, interest from international partners and funding for the production).
\end{abstract}

Keywords: Animation industry; Creative industries; TV Production; Competitiveness; Creativity.

\section{UN ESTUDIO EXPLORATORIO SOBRE LA INDUSTRIA BRASILEÑA DE ANIMACIÓN DE TV}

\begin{abstract}
RESUMEN
La economía creativa ha recibido poca atención por parte de la comunidad académica, a pesar de su importancia económica y cultural. Este artículo pretende contribuir a la literatura sobre el tema y se centra en la industria de animación, más precisamente en la producción de animación para la TV, ya que el país produjo recientemente animaciones de éxito en la televisión de pago, no sólo en Brasil, sino también en vario países. En este sentido, el trabajo analiza cómo los productores nacionales lograron tener éxito en sus producciones en un mercado dominado por los estudios internacionales. Para lograr este propósito se realizó un estudio exploratorio descriptivo analizando tres productoras (Flamma, TV y Pingüim 2DLab) que exhiben su producto en el canal Discovery Kids, dirigido a la audiencia preescolar. Se entrevistó a todos los miembros de los productores (para un total de seis, dos de cada fabricante), además de un representante de la animación para la industria cinematográfica. Además de las entrevistas, se utilizó información secundaria, recogidas principalmente en los medios de comunicación (periódicos, revistas e Internet). La investigación reveló que el éxito de los productores se produjo por una convergencia de factores relacionados con la capacidad de producir, la movilización de los productores independientes y el entorno institucional de la industria que se formaron en la primera década de este siglo con la ayuda del gobierno para
\end{abstract}

$$
\text { REAd | Porto Alegre - Edição } 78 \text { - Nº } 2 \text { - maio/agosto } 2014 \text { - p. 461-495 }
$$


Wilian Gatti Junior, Marilson Alves Gonçalves (in memoriam) \&

Ana Paula Franco Paes Leme Barbosa

promover la industria de la animación en el exterior y las líneas de crédito de apertura para la producción.

Palabras Clave: Industria de animación, Industrias Creativas, Producción de TV, Competitividad, Creatividad

\section{INTRODUÇÃO}

A economia (ou indústria) criativa tem recebido atenção de governos de diversos países, tanto pela sua capacidade de gerar empregos quanto divisas. O Brasil está nessa lista. Em janeiro de 2011, o Ministério da Cultura anunciou a criação da Secretária da Economia Criativa, com o objetivo de criar e desenvolver programas para desenvolver o setor, que viu a exportação de seus produtos aumentar de US\$ 2,4 bilhões em 2002 para US\$ 7,5 bilhões em 2008 (BRASIL, 2011).

Este artigo procura contribuir com a literatura tendo como foco um crescente mercado inserido nesse contexto: a indústria de animação. A animação reúne diversas características que a habilita a ser considerada um bom negócio: é relativamente simples de ser produzida, é multicultural (basta dublar a voz dos personagens para ela parecer ser de outro país), dura muito tempo (personagens são atemporais, passam por gerações) e os personagens podem render ao estúdio um bom retorno financeiro pelos contratos de licenciamento, uma vez que os heróis dos desenhos não se envolvem em escândalos em sua vida privada como seus concorrentes humanos (artistas e esportistas).

Yoon e Malecki (2009) mostram que, entre 1930 e 1980, o modelo de produção de animações baseava-se em dois tipos básicos: um sistema artesanal e outro produzido em Hollywood (globalizado). Enquanto o primeiro baseava-se na qualidade artística da produção, o segundo já diferenciava produção para cinema de produção para TV. Para o cinema o foco era a produção com apelo para o mercado; para a TV o foco estava voltado para metas de baixo custo e atendimento a cronogramas. Todavia, ao longo dos últimos anos, a indústria de animação sofreu grandes modificações com reflexos no mercado mundial. A partir de 1980, com a entrada dos computadores na indústria, a produção se diversificou. O sistema artesanal de produção (ex.: "Wallace e Gromit” da Aardman) manteve seu foco, mas precisou receber muito mais subsídios para sobreviver. A produção bidimensional (largura e altura), conhecida como animação 2D, para o cinema, foi reduzida drasticamente após o lançamento de "Toy Story”, da Pixar, em 1995 e a indústria se voltou para o uso intensivo de imagens geradas por computador (computer-generated imagery - CGI), animações em 3D (não é a projeção REAd | Porto Alegre - Edição 78 - N 2 - maio/agosto 2014 - p. 461-495 
Um estudo exploratório sobre a indústria brasileira de animação para a TV

estereoscópica, ela apenas dá ao espectador a noção de profundidade), altos custos (“Toy Story” de 1995 teve um orçamento de US\$ 30 milhões, “Toy Story 2” de 1999 US\$ 90 milhões e “Toy Story 3” de 2010 com estimados US\$ 200 milhões) e naturalmente, altos riscos. Na animação para a TV (ex.: Bob Esponja da Nickelodeon), a manutenção de foco em baixo custo se manteve pela limitação dos recursos técnicos empregados na produção e surgiram mercados domésticos como os de vídeo e DVD (home entertainment) orientados para o nicho de público pré-escolar (ex.: série Baby Einstein da Disney).

No Brasil, a indústria de animação está atravessando um momento singular em sua trajetória, tanto pela quantidade de produções, quanto pela qualidade do que está sendo exibido. A produção de animações para o cinema sofre muito com a concorrência da produção norte-americana, mas apesar das dificuldades, quinze longas-metragens estão sendo produzidos. Embora o número pareça tímido quando comparado aos padrões dos principais mercados, deve se considerar que, nos últimos noventa anos, o país só produziu vinte e três longas-metragens (TV BRASIL, 2011).

Na produção para a TV, os resultados são ainda mais significativos. Em um mercado global que movimentou 158 bilhões de dólares em 2009 (DALMAZO, 2009), três animações desenvolvidas por produtores brasileiros alcançaram expressivo sucesso na TV paga, em um canal com o maior número de assinantes e maior audiência entre todos os canais por assinatura no Brasil - o Discovery Kids, que pertence ao grupo americano Discovery Communications.

O alcance da conquista pode ser medido quando se observa a grade de programação do canal. Na semana de 31/10/2011 a 06/11/2011, o Discovery Kids levou ao ar 39 atrações, sendo 34 animações. Destas, 13 foram produzidas com alguma participação de estúdios americanos, 10 por canadenses e 8 por ingleses. Os espanhóis participaram de três animações, o mesmo número dos brasileiros. Desde a chegada dos canais de TV paga ao Brasil (meados dos anos 1990) é a primeira vez que tantas animações produzidas no país estão em exibição (até 2008 não havia nenhuma). Além disso, as animações brasileiras estão sendo exibidas em diversos países e ajudam a dezenas de empresas a vender seus produtos graças ao carisma dos seus personagens. Quando se observa o número de estúdios nos países que dividem a grade com as animações brasileiras, a conquista ganha contornos épicos. Nos EUA estão em funcionamento 1.211 estúdios de animação, contra 376 na Inglaterra, 354 no Canadá, 108 na Espanha e apenas 38 no Brasil (YOON, 2008).

REAd | Porto Alegre - Edição 78 - N 2 - maio/agosto 2014 - p. 461-495 
Wilian Gatti Junior, Marilson Alves Gonçalves (in memoriam) \&

Ana Paula Franco Paes Leme Barbosa

Desse modo, este trabalho tem como objetivo entender como produtoras nacionais conseguiram criar, produzir e exibir seu conteúdo na TV num mercado historicamente dominado por grandes estúdios internacionais. Compreender como essas produtoras brasileiras desenvolveram vantagens competitivas que as permitiram entrar nesse mercado, revela uma interessante linha de pesquisa ligada à indústria criativa do país, o que se traduz em novas questões de pesquisa, também descritas ao final deste artigo. Para atingir esse objetivo, a pesquisa investigou três casos de sucesso (produtoras Flamma, TV PinGuim e 2DLab) e suas animações voltadas para o público pré-escolar.

\section{REVISÃO DA LITERATURA}

Para entender o sucesso dos estúdios brasileiros no setor de animação, essa revisão se dedica a explicitar três importantes tópicos dessa indústria (produção, mercado e polaridades). Antes, porém a primeira parte dessa seção se dedica a uma breve revisão sobre os estudos ligados as fontes de vantagem competitiva. Em seguida, serão abordados os temas típicos dessa indústria. Primeiro, o processo de produção de uma animação com a caracterização das etapas percorridas. Segundo, a revisão procura caracterizar os principais mercados e o contexto competitivo e regulatório onde estão inseridos os estúdios nacionais. Por fim, uma breve discussão das chamadas polaridades enfrentadas pelos empreendedores desse segmento, que colocam em conflito objetivos, como por exemplo, a manutenção do valor artístico da obra com o resultado financeiro obtido com a aceitação do grande público.

\subsection{Vantagem competitiva}

A vantagem de perceber tendências de mercado à frente dos concorrentes e de ajustar a oferta em função dessa antecipação (ANSOFF, 1965) foi uma das primeiras definições dada à expressão vantagem competitiva. Esse entendimento foi ao longo do tempo aprofundado por outros autores e atualmente podemos compreender a vantagem competitiva como a oferta de produtos e serviços por uma empresa de uma maneira que claramente a distingue da concorrência, a um valor superior a sua confecção. Esse valor está relacionado à disposição dos compradores em pagar por algo (PORTER, 1986).

Dois eixos principais, um que considera a vantagem competitiva como um atributo de posicionamento, exterior à organização, derivado da estrutura da indústria, da dinâmica da concorrência e do mercado (ex.: PORTER, 1986) e outro que abrange teorias que a 
Um estudo exploratório sobre a indústria brasileira de animação para a TV

consideram decorrente de características internas da organização (ex.: EISENHARDT e MARTIN, 2000) auxiliam a compreender a questão da vantagem competitiva.

A lógica causal do posicionamento porteriano considera a estrutura da indústria determinando o comportamento dos agentes econômicos que define o desempenho da firma, sendo o sucesso função de duas áreas: a atratividade de indústria e o posicionamento relativo da empresa (PORTER, 1991). Tal posicionamento é alcançado pela estratégia adotada pela empresa em busca de proteger a firma da ação das forças competitivas, o que é possível pela construção de barreiras de entrada a outras indústrias. Nessa perspectiva, a questão da estratégia está orientada à noção de adaptação, pois a partir da escolha da melhor posição a firma deve configurar suas atividades de maneira coerente.

Direcionando o enfoque mais à firma que à indústria, está a corrente que considera os recursos e as competências da empresa como fontes centrais de vantagem competitiva. Essa linha de pesquisa defende a competitividade da empresa baseada em seus recursos, mais conhecida como a visão baseada em recursos (resource-based view - RBV). A RBV entende que os recursos empresariais são o núcleo central da formatação de estratégias de criação de valor. Os recursos podem ser entendidos como equipamentos especializados, localização geográfica (recursos físicos), pessoas e suas habilidades específicas (recursos humanos), bem como uma força de vendas bem estruturada (recursos organizacionais) (EISENHARDT e MARTIN, 2000). Tais recursos e competências são raros e de difícil imitação (BARNEY, 1991). Barney (1997) destaca as condições históricas únicas do desenvolvimento dos recursos e das competências da organização contribuindo na construção da vantagem competitiva. Nessa abordagem baseada em recursos pode-se observar a proposta da escola de design (MINTZBERG, AHLSTRAND e LAMPEL, 2010) com seu modelo de análise das forças e fraquezas que se volta para analisar internamente a organização combinando com uma perspectiva externa das oportunidades e ameaças. Nessa abordagem a competitividade se fundamenta essencialmente na capacidade de selecionar e combinar recursos adequados e mutuamente complementares (VASCONCELOS e CYRINO, 2000). É característico dessa combinação, a dificuldade de imitação pelos concorrentes que é dada por fatores naturais, legais, institucionais, além de fatores econômicos e organizacionais.

REAd | Porto Alegre - Edição 78 - Nº 2 - maio/agosto 2014 - p. 461-495 
Wilian Gatti Junior, Marilson Alves Gonçalves (in memoriam) \&

Ana Paula Franco Paes Leme Barbosa

\subsection{A produção de animações}

A produção de animações para TV se apoia em um sistema bem conhecido e consolidado que se aproxima mais ao conceito industrial do que propriamente artístico. Nos últimos anos, a grande mudança foi a substituição do desenho em papeis pela utilização de computadores no processo. De forma resumida, a produção percorre quatro estágios: (1) Conceito ou Desenvolvimento; (2) Pré-produção; (3) Produção e (4) Pós-produção (TSCHANG e GOLDSTEIN, 2004; WINDER e DOWLATABADI, 2001).

A partir da ideia do personagem e do conceito da série, surge na fase de Desenvolvimento, um resumo, muito breve, de cada episódio (story lines). As sinopses ou argumentos derivam das story lines e são formas mais detalhadas de contar a estória com a descrição dos acontecimentos de cada episódio. Após a aprovação da sinopse é produzido o roteiro, que descreve, com base nos acontecimentos descritos na sinopse, todas as cenas e os diálogos. Paralelamente, a produtora produz a bíblia, como é chamado o livreto com o desenho de todos os personagens, suas características e as story lines que vão compor a série. A bíblia é apresentada nas reuniões onde são discutidas as vendas (pitchs) do projeto tanto para canais de TV quanto para distribuidores.

A fase de Pré-produção se inicia com a materialização dos roteiros em storyboards (hoje já feito em computadores), uma espécie de história em quadrinhos do episódio. Para cada cena é feito um desenho, o que em um episódio típico de TV (11 minutos) gira em torno de 200 a 400 desenhos. O conjunto de storyboards que compõem o episódio fica pronto em torno de uma a duas semanas. Isso ajuda a minimizar erros e a evitar retrabalhos na fase de produção, reduzindo assim o tempo e o custo do projeto. Após o storyboard ser aprovado, ele é montado de forma sequencial e é levado ao estúdio de locução para a gravação das vozes dos personagens (diálogos). Como o episódio possui um tempo fixo, essa fase ajuda a verificar se o episódio está cumprindo essa exigência, além de ser um processo delicado que exige sensibilidade dos produtores, pois a voz dos personagens é um dos elementos chave para cativar o telespectador e criar uma relação simpática com eles.

Na fase de Produção tem inicio a animação propriamente dita, isto é, a sobreposição de desenhos (frames) que dá a ilusão de movimento dos personagens. São, então, desenhados os movimentos de cada cena, como uma primeira camada, que depois serão colocados sobre os cenários (desenhados por outra parte da equipe) na fase de Pós-Produção. Os estúdios que trabalham com animação computadorizada (paperless) em 2D, perseguem uma meta de 
Um estudo exploratório sobre a indústria brasileira de animação para a TV

produtividade de 6 segundos de animação por dia por animador, o que equivale a 30 segundos por semana por animador (considerando as técnicas hoje empregadas para séries de TV). Alguns estúdios, fora do Brasil, chegam a trabalhar com 40 a 45 segundos por semana por animador. Para se ter uma ideia, um segundo equivale a 24 desenhos.

Na fase de Pós-produção, além de concatenar a movimentação dos personagens com o cenário, é inserida a trilha sonora e as vozes e assim o episódio é finalizado. Embora simples, o processo é custoso sendo essa uma das principais barreiras para o incremento da animação nacional. Diversos fatores contribuem para o elevado custo no Brasil. Primeiro, o tamanho da equipe. A maior parte do custo está atrelada ao tempo dedicado à produção da animação (horas/homem) e à lei trabalhista no Brasil que dobra o custo da produção devido a encargos trabalhistas. Segundo, o cronograma apertado, que consome mais recursos para cumpri-lo, atrelado à qualidade exigida pelo projeto. Por último, a tecnologia, em outras palavras o uso de computadores para o desenvolvimento da animação. Atualmente, ela não é um diferencial competitivo. A disseminação da internet e dos computadores fez o preço cair, mas em comparação aos mercados americanos e canadenses, por exemplo, os equipamentos (monitores que permitem que se desenhe direto neles) são muito caros para equipar um estúdio, principalmente pela tributação brasileira.

Uma típica produção realizada no Brasil, em média, tem a seguinte estrutura de custos: 10\% dedicado ao roteiro, 60\% para a animação e 30\% ao restante (ex.: divulgação). Numa produção americana, 50\% dos custos são incorridos em divulgação e os demais ficam divididos na proporção anterior entre roteiro e animação. Produzir animação é, portanto, algo caro para um país sem tradição no setor, mas com necessidade de competir no mercado internacional. Assim, para viabilizar sua produção, os estúdios brasileiros têm buscado acordos de coprodução.

\subsection{0 mercado de animação}

Os maiores mercados de animação são os EUA, Japão, Canadá, França, Reino Unido e Alemanha (RAUGUST, 2004; TSCHANG e GOLDSTEIN, 2004). O destaque da produção, porém, recai sobre a indústria norte-americana (para o cinema e TV) e sobre a canadense (para a TV).

Os EUA desenvolveram duas indústrias de animação expressivas, com estúdios de diversos tamanhos, tanto para a produção de cinema, quanto para a produção de $\mathrm{TV}$, 
Wilian Gatti Junior, Marilson Alves Gonçalves (in memoriam) \&

Ana Paula Franco Paes Leme Barbosa

entretanto são os grandes estúdios que se destacam no país. No cinema, essa tendência é bem conhecida e na TV, três grandes canais (Disney, Time Warner’s Cartoon Network e Viacom’s Nickelodeon) possuem em sua estrutura o estúdio, a distribuição e o licenciamento (RAUGUST, 2004; YOON e MALECKI, 2009). Mesmo quando surgem animações para a TV - feitas pelas produtoras independentes - elas são praticamente incorporadas pelas grandes redes. Nesse mercado de grande potencial e consumo, o orçamento (em geral muito alto) e uma massiva divulgação tornam imbatíveis a quantidade de produções, a qualidade do que é exibido e os elevados retornos de bilheteria. Além disso, os grandes produtores conseguem licenciamento no mundo inteiro, sem pagar intermediários, pois são donos dos canais e assim podem distribuir e ganhar muito na produção. Com a crise econômica de 2008, os estúdios americanos começaram a buscar coproduções, o que em parte, sinaliza o início do esgotamento deste modelo ganhador.

Os canadenses são reconhecidos por possuírem uma estrutura consolidada voltada à produção independente e com experiência na TV, onde os canais atuam basicamente como retransmissores de conteúdo, não tanto como criadores. O país abriga estúdios de médio e pequeno porte, muitos deles, key players na produção e distribuição mundial de animações para a TV (ex. Nelvana, Cookie Jar, Mainframe e CinéGroupe) (RAUGUST, 2004). Para fugir da influência cultural norte-americana, no final dos anos 1980, o governo canadense criou barreiras para a exibição de animações e passou a promover acordos de coprodução com outros países. A partir daí, a indústria se consolidou, muitos produtores viabilizam suas animações com acesso a recursos do governo e muitas distribuidoras instaladas garantem a exibição do produto em vários países, além de trabalharem quase que exclusivamente com coproduções. As Filipinas e a França têm feito muitos trabalhos de coprodução com Canadá. Mais recentemente, o Brasil foi visto como um potencial parceiro.

No Brasil, a indústria de animação é um fenômeno relativamente recente. Na verdade, o setor entende que não há efetivamente uma indústria formada. Para isso seria necessário ter uma produção consistente, onde os estúdios (como em uma linha de produção) pudessem coordenar um trabalho após o outro. Porém, o maior desafio do mercado é conseguir viabilizar financeiramente as produções. Mesmo com modelos diferentes de financiamento, os EUA, o Japão (impulsionados pela iniciativa privada), o Canadá e a Europa (apoiados por recursos públicos) possuem mais recursos para financiar a produção de animações. Por sua 
Um estudo exploratório sobre a indústria brasileira de animação para a TV

vez, os estúdios brasileiros são capazes de competir em termos técnicos e em criatividade, mas lhes faltam recursos.

Outro desafio desta indústria é que a animação tem um retorno demorado. O licenciamento, uma das principais fontes do estúdio, só gera resultados após a produção, exibição e aceitação do público, um ciclo que pode levar mais de dois anos. Assim, as produtoras nacionais mantêm atividades paralelas, intercalando produções com trabalhos publicitários, para garantir a renda e o funcionamento da produtora.

Como em vários outros setores, o momento da animação brasileira é visto sob a ótica das oportunidades e desafios. Desde a criação da Lei Rouanet (Lei 8.313/91) e dos artigos $1^{\circ}$ e $3^{\circ}$ da Lei do Audiovisual (Lei 8.685/93), o setor não recebia atenção do governo brasileiro para a criação de incentivos com relação ao financiamento da produção cinematográfica. Esse cenário começou a ser modificado em 2002, quando começou a vigorar a cobrança da Contribuição para o Desenvolvimento da Indústria Cinematográfica Nacional (CONDECINE) destinada à Agência Nacional de Cinema (ANCINE) - com base na Medida Provisória ${ }^{\circ}$ 2.228/01. A CONDECINE passou a taxar em 11\% o envio "aos produtores, distribuidores ou intermediários no exterior, de importâncias relativas a rendimento decorrente da exploração de obras cinematográficas e videofonográficas ou por sua aquisição ou importação" (ANCINE, 2011). O artigo 39 da medida prevê, porém que a empresa que optar em destinar $3 \%$ do valor do crédito ou remessa em obras audiovisuais de produtoras independentes estariam isentas da Condecine.

A movimentação positiva dos agentes que produzem, promovem e financiam a animação no país pode ser vista como geradora de oportunidades. A articulação do setor tem início em 1999, quando uma série de produtoras independentes fundou a Associação Brasileira das Produtoras Independentes de Televisão (ABPI-TV), convencidos que juntos (em 2011 eram 159 empresas associadas) poderiam divulgar melhor a produção independente, entre ela a animação, e buscar os recursos para viabilizá-la. Em 2004, o grupo criou a Brazilian TV Producers (BTVP) por meio de uma parceria com a Agência Brasileira de Promoção de Exportações e Investimentos (APEX-BRASIL) e a Secretaria do Audiovisual do Ministério da Cultura (SAv/MinC). O objetivo da BTVP é capacitar (com treinamentos) e ajudar (com subsídios financeiros) o produtor brasileiro a competir no exterior, dando suporte para a participação em feiras do setor (ex.: MIPTVP, MIPCOM, Realscreen, Kidscreeen, BANFF). Nessas feiras os produtores podem utilizar o estande brasileiro montado pela BTVP 
Wilian Gatti Junior, Marilson Alves Gonçalves (in memoriam) \&

Ana Paula Franco Paes Leme Barbosa

com salas de reuniões e serviços. O intuito é criar relacionamentos nos congressos e passar credibilidade ao produtor e distribuidor internacionais. Na edição de 2011 da MIPCOM (feira de audiovisual que ocorre anualmente em Cannes, França), estiverem presentes trinta e cinco produtoras brasileiras, quatro emissoras de TV aberta (Globo, SBT, Record e Bandeirantes), além da ANCINE e do Banco Nacional de Desenvolvimento Econômico e Social (BNDES) (CALDEIRA, 2011).

O envolvimento do BNDES com o setor começou em 2007, com o anunciou da criação do Programa de apoio à Cadeia Produtiva do Audiovisual (Procult), realizado durante o primeiro encontro da ABPI-TV. O Procult é uma linha especial de crédito para as áreas de produção, infraestrutura, distribuição, comercialização e exibição de conteúdo audiovisual. O Programa contou com um orçamento até 30/06/2013 da ordem de R\$ 1,5 bilhão, com limites anuais de R\$ 500 milhões (BNDES, 2013).

Em agosto de 2011, a ABPI-TV comemorou a aprovação da Lei 12.485/11 que permitiu as empresas de telefonia oferecer pacotes com TV, telefone e acesso à internet, acabando com o limite de investimento estrangeiro em operadoras de TV paga e estabelecendo cotas de programação brasileira para os canais de TV (incluindo os canais internacionais). As cotas incluem a veiculação obrigatória de três horas e meia de produção regional e nacional por semana, em horário nobre, sendo metade dessa programação produzida por produtoras independentes. Além disso, os pacotes de canais devem conter um terço de canais brasileiros. Dentre eles, um terço deve ter produção independente e dois terços de canais devem ter 12 horas diárias de programação brasileira com conteúdo independente. A ABPI-TV estima que a lei possa dobrar a produção independente para a TV e consequentemente de animações.

Outro fator importante para o momento da indústria de animação no país foi a crise de 2008. Enquanto os recursos no resto do mundo diminuíram, o Brasil, que não sofreu muito os impactos econômicos da crise, passou a ser encarado como um mercado interessante, não só pelo seu grande potencial de consumo, mas como um parceiro para a produção de animações.

Se por um lado o setor vislumbrou oportunidades com os novos incentivos e ações conjuntas, por outro constatou que alguns desafios precisavam ser superados. Entre eles destacam-se a falta de uma aproximação entre TV e produtoras independentes (que pode ser contornada com a Lei 12.485/11) e a baixa capacitação profissional. A carência observada de profissionais é ainda maior no que se refere à produção de roteiros. É relativamente fácil 
Um estudo exploratório sobre a indústria brasileira de animação para a TV

encontrar brasileiros que desenham, mas é muito difícil encontrar bons roteiristas, o que pode parecer um paradoxo, pois o brasileiro é visto no exterior como criativo graças à música e artes em geral. Na área de animação, o diretor Carlos Saldanha, que trabalhou em produções de sucesso como “A Era do Gelo” (2002, 2006 e 2009) e “Rio” (2011), ajudou a projetar essa imagem. Parte do problema pode ser explicado pelo pouco envolvimento do brasileiro com a literatura - se lê muito pouco no país. Na visão das produtoras, se o Brasil quer se posicionar como um país gerador de ideias, isso precisa mudar. Hoje o país é um player no mercado internacional e passa a ser percebido como país que cria e vende ideias. Para manter essa posição, o Brasil precisaria investir em roteiristas. Não basta criar bons desenhos, é necessário criar personagens interessantes e boas estórias para vender bons conceitos, pois a rentabilidade está centrada no criador de conteúdo.

\subsection{Polaridades na indústria criativa}

Além das dificuldades impostas a qualquer projeto, a produtora deve conciliar a imprevisibilidade da demanda e a dificuldade de monitorar e controlar o processo de produção, bem como, deve acomodar forças antagônicas que se expressam, na visão de Lampel, Lant e Shamsie (2000), em polaridades.

A primeira delas diz respeito ao conflito inerente à manutenção dos valores artísticos em sua obra ou, alternativamente, a produzir uma animação para o entretenimento de massa. Assim, o produtor constantemente avalia os seus ideais e aspirações com o valor de mercado que sua obra deve gerar. O segundo ponto a ser observado é a polaridade existente entre a diferenciação de produto versus a inovação de mercado. Aqui, o estúdio enfrenta a dificuldade em ter que inovar, para imprimir sua marca criativa e tornar sua animação diferente das demais, porém não a ponto de deixá-la tão diferente que não seja atraente ou compreensível para o público.

Lampel, Lant e Shamsie (2000) também descrevem como polaridade o modo como a animação é criada. Por um lado, a produtora pode fazer uma análise da demanda, perceber e investigar a preferência dos consumidores e a partir daí moldar seu produto para atender a esses requisitos, por outro, deliberada ou acidentalmente, a produtora pode moldar os gostos do seu público e por isso são bem sucedidas. Além disso, a estratégia de integração vertical versus especialização flexível também preocupa o executivo, que deve analisar e escolher entre os diferentes modelos. Por fim, o setor deve lidar com a polaridade existente entre a 
Wilian Gatti Junior, Marilson Alves Gonçalves (in memoriam) \&

Ana Paula Franco Paes Leme Barbosa

visão centrada na inspiração individual, que defende que os indivíduos criativos são o elemento central na cadeia de valor, versus a visão centrada no compartilhamento (pooling view), que defende que o sistema como um todo possui os elementos para impulsionar o processo criativo e de sucesso da indústria.

\section{METODOLOGIA}

Novos paradigmas vêm questionando os pressupostos e procedimentos que orientam a pesquisa científica (ALVES-MAZZOTI e GEWANDSZNAJDER, 2001), o que de certo, abre espaço para a pesquisa qualitativa, historicamente vista como “inferior” ante ao rigor da investigação quantitativa.

A pesquisa qualitativa, definida como o conjunto de técnicas que visam interpretar a realidade, dando preferência aos aspectos mais analíticos que tem por objetivo descrever e decodificar os componentes de um sistema complexo de significados (NEVES, 1996), começou a aparecer no cenário da pesquisa social, a partir da segunda metade do século XIX (GODOY, 1995), na Antropologia e Sociologia, e nas últimas três décadas recebeu grande aceitação em áreas como Administração, Psicologia, e Educação (NEVES, 1996). Este tipo de pesquisa, na visão de Denker e Viá (2001), presume o contato direto do pesquisador com o ambiente e a situação que está sendo investigada. Diante da possibilidade de contato dos pesquisadores com agentes da situação pesquisada e da complexa interação de fatores relacionados a essa pesquisa, que visa entender o sucesso de três produtoras brasileiras no segmento de animação para a TV, a abordagem qualitativa foi a escolhida para a condução desse estudo.

Este trabalho se enquadra na definição de estudo exploratório, pois se pretendeu aumentar o conhecimento sobre o fenômeno estudado e o estabelecimento de prioridades para futuras pesquisas, onde serão formulados problemas mais precisos e novas hipóteses (SELLTIZ et al., 1975). Contribui também para a caracterização desta pesquisa como exploratória, a ausência de pesquisas como o aqui conduzido no contexto brasileiro. Além de exploratório, este estudo se caracteriza também como descritivo por analisar e descrever as características do fenômeno estudado (FERNANDES e GOMES, 2003).

A unidade de análise se concentra em três produtoras nacionais (Flamma, TV PinGuim e 2DLab) que marcaram a nova fase da indústria de animação brasileira. Para a

REAd | Porto Alegre - Edição 78 - Nº 2 - maio/agosto 2014 - p. 461-495 
Um estudo exploratório sobre a indústria brasileira de animação para a TV

coleta de dados foram realizadas entrevistas semiestruturadas e fontes secundárias (basicamente matérias publicadas na mídia).

Os contatos iniciais foram feitos previamente por e-mail com um texto que explicava as razões da pesquisa e uma solicitação de entrevista. As entrevistas foram realizadas pessoalmente, no caso dos sócios da TV PinGuim, e pela internet (Skype) com os demais. Ao final das entrevistas era solicitada a permissão para a identificação de todos os envolvidos (pessoas físicas e jurídicas) e a divulgação de todas as informações coletadas (apenas para fins acadêmicos). Ao todo foram sete entrevistas, duas em cada uma das empresas escolhidas e uma com a ex-presidente da Associação Brasileira de Cinema de Animação (ABCA), como descritas no quadro a seguir:

Quadro 1 - Entrevistas realizadas

\begin{tabular}{clcll}
\hline Data & Empresa & Duração da Entrevista & Entrevistados & Posição do Entrevistado \\
\hline 17/05/2011 & TV PinGuim & $1 \mathrm{~h}$ & Célia Catunda & Sócia proprietária \\
$07 / 07 / 2011$ & TV PinGuim & $1 \mathrm{~h}$ & Kiko Mistrorigo & Sócio proprietário \\
19/09/2011 & 2DLab & $1 \mathrm{~h}$ & André Breitman & Sócio proprietário \\
30/09/2011 & Flamma & $0 \mathrm{~h} 30$ & Fábio Yabu & Ex-sócio proprietário \\
$06 / 10 / 2011$ & 2DLab & $1 \mathrm{~h}$ & Andrés Lieban & Sócio proprietário \\
$13 / 10 / 2011$ & Flamma & $0 \mathrm{~h} 45$ & Reynaldo Marchezini & Sócio proprietário \\
$14 / 10 / 2011$ & ABCA & $1 \mathrm{~h}$ & Marta Machado & Ex-presidente ABCA \\
\hline
\end{tabular}

Fonte: autores deste estudo

Cada uma das entrevistas reunia dois propósitos básicos: conhecer a história por trás dos casos de sucesso e entender o contexto nacional e internacional do mercado de animação. A estratégia básica para minimizar o problema da subjetividade dos dados coletados foi a utilização de múltiplas fontes de coleta de dados. Por isso se optou por entrevistar mais de um sócio individualmente e em datas diferentes. Além desse fato, esta pesquisa reuniu o depoimento de mais de uma empresa e mais de um sócio pela possibilidade de se destacar os pontos em comum e as diferenças observadas, com o objetivo de dar maior robustez às evidências coletadas (McCUTCHEON e MEREDITH, 1993; YIN, 2005). Os relatos foram anotados em blocos de papel (apenas as entrevistas de 07/07 e 19/09 não foram gravadas) e depois transcritos em um processador de texto.

A análise dos dados foi estruturada dentro de um processo resumido em quatro etapas. Na primeira etapa foi feita a reconstrução das entrevistas em formato de narrativa, isto é, a partir dos dados coletados nas entrevistas, uma narrativa (para cada entrevista) foi produzida em formato eletrônico, considerando, principalmente, as evidências que tiveram estreita ligação com os objetivos da pesquisa. De posse da narrativa de cada um das empresas, na REAd | Porto Alegre - Edição 78 - Nº 2 - maio/agosto 2014 - p. 461-495 
Wilian Gatti Junior, Marilson Alves Gonçalves (in memoriam) \&

Ana Paula Franco Paes Leme Barbosa

etapa seguinte, procedeu-se a análise individual das narrativas. Ela teve início com análise do conteúdo, por meio da codificação dos dados, com base nas fases e requisitos para a produção das animações, nos resultados mercadológicos que cada produtora alcançou e como cada produtora realizou o gerenciamento das polaridades estudadas. Essa foi a codificação aberta, quando se procedeu a leitura crítica das narrativas e identificação dos trechos para cada uma dessas analises (GIBBS, 2009). Na terceira etapa, houve um refinamento desta codificação, quando o conteúdo de cada categoria foi confrontado com citações extraídas da literatura. $\mathrm{O}$ resultado desta fase foi exibido em quadros demonstrativos capazes de representar de maneira sistemática e visual, as informações e dados coletados (vide quadros 2, 3 e 4) (MILES e HUBERMAN, 1994).

Com a análise individual das narrativas concluída na quarta e última etapa, foi realizada a análise comparativa com o objetivo de encontrar pontos em comum e diferenças que pudessem ser observadas (EISENHARDT, 1989).

O processo de análise promoveu o abandono, a modificação ou a manutenção de inferências inicialmente elaboradas na análise das narrativas individuais, sendo reportadas no relatório final aquelas que podiam ser sustentadas pelos depoimentos dos executivos entrevistados.

\section{EMPRESAS ESTUDADAS}

\subsection{Flamma}

A Flamma, produtora da capital paulista, foi fundada em meados de 2004, por dois sócios, Reynaldo Marchezini e Fábio Yabu. Mesmo percorrendo caminhos distintos, ambos acumulam larga experiência na chamada indústria criativa.

Reynaldo está envolvido com a produção de animações desde os tempos em que trabalhava como animador, enquanto fazia a faculdade de engenharia elétrica na Fundação Armando Álvares Penteado (FAAP), no final dos anos 1980. Entre 1999 e 2003, atuou como gerente de marcas e executivo de vendas em uma empresa de distribuição de conteúdo para o mercado brasileiro (Mega Distribuidora) que representava marcas como Nelvana, Southern Star, Disney, BBC e Nintendo. Já Fábio se destacou como escritor e criador de história em quadrinhos voltados para o público infanto-juvenil. É dele a criação de Princesas do Mar que foi produzido pela Flamma e é sucesso na Discovery Kids.

REAd | Porto Alegre - Edição 78 - N 2 - maio/agosto 2014 - p. 461-495 
Um estudo exploratório sobre a indústria brasileira de animação para a TV

Em 2002, Fábio viu seu projeto de um personagem para uma campanha publicitária ser reprovado pelo cliente. A princesa que vivia no fundo do mar pode não ter ganhado a conta, mas fez Fábio se entusiasmar com a ideia de criar outras princesas e juntas as amigas iriam viver aventuras em um mundo submarino. Surgiram assim Polvina (a princesa do reino dos polvos), Ester (a princesa do reino das estrelas-do-mar) e Tubarina (a princesa do reino dos tubarões). Em cada episódio, as três se envolvem em situações complicadas onde o espírito de equipe e a amizade sempre se sobressaem. A série, entretanto não havia sido criada para a TV. Por dois anos (entre 2002 e 2004) Fabio trabalhou no conceito e transformou as Princesas em uma série de livros publicados pela Panda Books de São Paulo.

Com o sucesso dos livros veio à ideia de produzir uma animação para contar a estória das pequenas princesas na TV e para o mundo. Com a fundação da Flamma esse objetivo poderia ser perseguido. O problema da nova empresa era exatamente a falta de referências. A empresa não tinha nenhum histórico, o que era um fator limitante para obter recursos no Brasil, pois os mecanismos de financiamento público estavam atrelados ao histórico da produtora. Sem sucesso, participaram de concursos e editais do governo. Restava então a opção de uma coprodução com alguma produtora internacional.

Com a experiência e os contatos do Reynaldo e o projeto do Fábio, juntos visitaram em outubro de 2004 a MIPCOM, onde realizaram 25 pitchs para vender basicamente duas ideias: um contrato de coprodução e, uma vez acertada a coprodução, trazer a parte de animação para o Brasil, pois a Flamma já havia sondado estúdios no país que poderiam fazer a animação da série. Desde seu início a Flamma não foi criada para ser um estúdio de animação (ela não tem animadores como funcionários), ela é uma produtora de conteúdo.

A ideia de coprodução foi bem aceita, mas ao mencionar a ideia de realizar atividade de animação no Brasil, houve resistência dos parceiros, pois o Brasil não tinha experiência, em outras palavras, não havia histórico de produção de séries no país. O resultado foi que dez empresas se motivaram a participar de uma coprodução com a Flamma, porém apenas quatro mostraram interesse real. Ao final do processo, Reynaldo e Fábio centraram a negociação com duas empresas.

Ao final do processo de negociação assinaram um contrato de coprodução, no final de 2004, com a maior produtora independente da Austrália, a Southern Star, responsável por sucessos no Brasil como "Bananas de Pijama” e "Hi-5”. No ano seguinte, um estúdio espanhol, Neptuno Films, entrou para produzir as animações. Diferente de todos os demais 
Wilian Gatti Junior, Marilson Alves Gonçalves (in memoriam) \&

Ana Paula Franco Paes Leme Barbosa

casos brasileiros, Princesas do Mar, foi a primeira coprodução internacional com ideia vindo da parte brasileira e financiamento de fora, sem uso de recursos brasileiros.

Acabaram fechando com os australianos um option agreement (contrato de opção) com validade de dois anos. Ao final de um ano e cinco meses os australianos levantaram os US\$ 7 milhões necessários para viabilizar a produção. Pode ser considerado um valor padrão de mercado, embora possa variar de acordo com o local onde será feita a animação (ex.: Índia, Coréia, Cingapura e China, em geral, animam a um custo mais baixo).

A Flamma também negociou a participação dos australianos nos direitos de propriedade de Princesas do Mar. Foi assim realizada uma divisão territorial da distribuição e exploração do licenciamento da série: a América Latina ficou com a Flamma, Portugal e Espanha com a Neptuno e o resto do mundo com os australianos, que já tem uma forte distribuição, com equipes de vendas em vários países. Mesmo com grandes concessões, o objetivo foi concretizado. A estratégia era viabilizar um primeiro projeto para dar visibilidade à empresa e com isso avançar em novos trabalhos.

A produção teve início em julho de 2006. A coordenação, produção executiva ficou com australianos, bem como a criação dos roteiros, storyboard e o a gravação das vozes dos personagens (o desenho é dublado em português quando exibido no Brasil). Coube à Flamma, o character design e a aprovação dos roteiros em conjunto com a Southern Star. Na Espanha foi feita toda a produção da animação e a pós-produção (edição, música, trilha, finalização etc.). A primeira temporada, com 52 episódios de 11 minutos, ficou pronta em 18 meses e logo na sequência foi produzida a segunda temporada. A maior parte do volume de trabalho e número de pessoas envolvidas (mais de 100) ficou na Espanha, mas a parte mais criativa foi desenvolvida pelas equipes no Brasil e na Austrália. Os espanhóis da Neptuno não tinham influência para mudar cenário, roteiro, personagens etc.

A série Princesas do Mar estreou em setembro de 2007 na Austrália e em março de 2008 no Brasil, na Discovery Kids (em 2010 estreou a segunda temporada). Além de Austrália e Brasil (hoje também na TV Cultura de São Paulo) a animação é exibida em outros 126 países.

O licenciamento dos produtos no Brasil se iniciou em 2008, após assinarem contrato com a Kasmanas, empresa do setor, e desde então as princesas já figuram em mais de 190 produtos. Segundo a Flamma, não há mais interesse em produzir uma nova temporada para 
Um estudo exploratório sobre a indústria brasileira de animação para a TV

Princesas do Mar. Hoje separados - Fabio Yabu deixou a Flamma em 2009 - cada sócio segue sua carreira atuando em outros projetos de animação.

\subsection{TV PinGuim}

A TV PinGuim foi fundada em 1989 por dois sócios (hoje são três com a entrada de Ricardo Rozzino): Célia Catunda e Francisco (Kiko) Mistrorigo. Os dois se conheceram ainda na faculdade, graças ao gosto comum por histórias em quadrinhos e animação. Kiko se formou na FAU (Faculdade de Arquitetura e Urbanismo da USP) onde Célia começou a estudar, mas ela abandonaria o curso para mais tarde se formar em Rádio e TV na ECA (Escola de Comunicação e Artes da USP). Embora não tenham formação em negócios, acreditam que a vocação empreendedora tenha vindo de casa. O pai de Kiko, médico, administra seu próprio consultório e o pai de Célia tem uma empresa de arquitetura.

A empresa foi uma das pioneiras na utilização de computação gráfica, operando equipamentos Apple. A realidade da TV PinGuim não era muito diferente de outras produtoras - viviam de publicidade - mas eles queriam produzir conteúdo usando tecnologia sem custo do filme e sem utilizar papel, porém a Lei de Informática que vigorava no país no final dos anos 1980, dificultou muito o início dos sócios.

A produção publicitária era suficiente para, na opinião dos sócios, “pagar as contas”, porém entendiam que o sucesso da produtora só viria com a produção de conteúdo próprio e gerenciamento de marcas e personagens ligados a cultura. Alimentavam assim o desejo de produzir séries diferentes das até então exibidas no país, em geral, imersas em um contexto diferente do que vivia a criança brasileira. Produziram então diversas animações de relativo sucesso na TV como “Rita” em 1994 e a série “De onde vem?” de 2002, ambos para a TV Cultura de São Paulo.

A empresa percebeu como oportunidade de negócios o boom de cartoons nos EUA, onde desde 1992, havia um canal exclusivo para animações (Cartoon Networks). Aliado a essa percepção, os sócio da TV PinGuim vislumbraram oportunidades com o artigo 39 da CONDECINE como incentivo a produção local de animações.

A ideia de uma série de desenhos usando um peixe como personagem principal começou por acaso. A partir de desenhos rabiscados durante uma palestra, Célia Catunda viu ali o potencial da ideia. Surgia assim o Peixonauta, um peixe misto de viajante, explorador e agente secreto que se envolve em problemas, em geral ligados a questões ecológicas, que 
Wilian Gatti Junior, Marilson Alves Gonçalves (in memoriam) \&

Ana Paula Franco Paes Leme Barbosa

ocorrem em um parque. O pequeno peixe com mais dois amigos, a menina Marina e o macaco Zico, recebem pistas vindas de uma bola colorida (a Pop) e, juntos, solucionam o mistério transmitindo valores como preservação do meio ambiente e trabalho em equipe.

Com a ideia dessa nova animação já formatada desde 2003, a TV PinGuim inicia seu projeto para uma inserção mais efetiva na indústria de animação. Já no ano seguinte, os sócios começaram visitando as feiras especializadas do setor (MIPCOM e MIPTV), em busca de parceiros para coprodução e diferentemente de outras produtoras nacionais que também visitavam a feira, já tinham 38 reuniões pré-agendadas. Na ocasião, iniciaram as negociações com a produtora canadense Nelvana, produtora de animações de sucesso no Brasil como “Os Backyardigans”, “Franklin”, “Miss Spider”, “Babar e as aventuras de Badou” entre outras.

Após vários contatos, a negociação evoluiu e a TV PinGuim fechou, na edição de 2005 da MIPCOM, um projeto de coprodução com a Nelvana. No Canadá, o modelo de captação de recursos prevê que a produtora tenha, como garantia do empréstimo, um contrato de exibição em uma TV local. Depois de um ano esse problema não foi equacionado. Para viabilizar a produção, a TV PinGuim assinou em 2006 um contrato de pré-venda da série com a Discovery Kids para o mercado brasileiro e da América Latina. Como o contrato impunha prazos apertados e os canadenses não poderiam auxiliar, o contrato de coprodução foi encerrado.

Com o contrato assinado com a Discovery, para uma temporada de 52 episódios de 11 minutos, a TV PinGuim deveria equacionar primeiro os recursos para produzi-la (US\$ 6 milhões) e depois fazê-lo no tempo contratado (18 meses). Mesmo com a dificuldade de obter os recursos (investimento), a Discovery sempre esteve disposta a negociar o cronograma.

Parte do investimento veio da Discovery, incentivada pelo artigo 39 da CONDECINE, que entrou como coprodutora ao fazer a pré-compra da animação. Outra parte de patrocínio da Bunge, cerca de R\$ 400 mil. A TV Pinguim buscou a parte restante junto a investidores. Apresentou o projeto a um grupo de investidores de risco em um evento da Agência Brasileira da Inovação (FINEP), vinculada ao Ministério de Ciência e Tecnologia. Nenhum resultado monetário foi obtido, mas a empresa aprendeu com a experiência a, por exemplo, montar um business plan. Um participante do evento, ligado à Agência Nacional do Cinema (ANCINE), apresentou a TV Pinguim ao BNDES. Após várias reuniões o financiamento foi obtido após a criação do Procult, mas mesmo assim, parte do investimento necessário foi completado com recursos próprios.

REAd | Porto Alegre - Edição 78 - Nº 2 - maio/agosto 2014 - p. 461-495 
Um estudo exploratório sobre a indústria brasileira de animação para a TV

A produção foi realizada em 22 meses. A empresa com 15 funcionários contou com a participação de 150 pessoas para a produção da $1^{\text {a }}$ temporada, a qual estreou no canal Discovery Kids em abril de 2009. Em pouco tempo, a animação brasileira tornou-se líder de audiência no canal. A gestão do projeto foi totalmente feita pela TV PinGuim. O canal se envolveu na supervisão de roteiros e aprovou, em conjunto com a produtora, os episódios finais.

Após o sucesso na Discovery Kids, a TV PinGuim, conseguiu licenciar e distribuir produtos com a marca Peixonauta. Como a TV PinGuim não tinha competência para gerenciar esse processo, acertou uma parceria com a Redibra, empresa com experiência na área de licenciamento. A marca está estampada em 300 produtos de 20 empresas.

Hoje, a série Peixonauta é transmitida em 67 países. Para os mercados da América Latina e EUA a distribuição ficou a cargo da Discovery Kids e a distribuição internacional é feita pela canadense Breakthrough Entretainment sob o nome Fishtronaut. A série também é sucesso na TV aberta brasileira no SBT e encabeça uma lista de projetos da TV PinGuim que envolve a $2^{\mathrm{a}}$ temporada para a TV, uma peça de teatro, um DVD musical e um longa metragem para o cinema.

\subsection{DLab}

Fundada na cidade de Porto Alegre em 1998, ainda com o nome Laboratório de Desenhos, a 2DLab começou, como grande parte das produtoras brasileiras, produzindo animações para o mercado publicitário. Primeiro para as agências da região e logo depois para todo o Brasil. Seu fundador, Andrés Lieban, é formado em Artes Plásticas pela Universidade Federal do Rio Grande do Sul (UFRGS) e trabalha com animações desde 1990. Entre seus projetos mais conhecidos estão episódios de TV do Alladin da Disney e da Turma da Mônica de Mauricio de Sousa.

Em 2003, o Laboratório de Desenhos produziu com a editora Delta, de André e Claudia Koogan Breitman a animação Aquarela, inspirada na música interpretada por Toquinho. No ano seguinte, os três se uniram para formar a 2DLab. Claudia é autora de peças de teatro, roteirista e tem mestrado em Dramaturgia pela Actors Studio Drama School da Pace University de Nova York. André, engenheiro elétrico formado pela PUC-RJ, acumula, desde 1990, experiência na produção de conteúdos culturais para TV, CD-ROM, internet, livros e revistas.

REAd | Porto Alegre - Edição 78 - Nº 2 - maio/agosto 2014 - p. 461-495 
Wilian Gatti Junior, Marilson Alves Gonçalves (in memoriam) \&

Ana Paula Franco Paes Leme Barbosa

Logo após à formação da 2DLab, isso por volta de 2004, o MinC do Brasil por meio da Secretaria do Áudio Visual emitiu editais específicos para animação (curtas e longas) que seriam exibidos na TVE com fomento para o roteiro (R\$ 10 mil) cujo tema era o "meu melhor amigo”. A 2DLab decidiu se inscrever e produziu um curta de 1 minuto intitulado "Meu Amigãozão” que ficou pronto em 2006. Era uma estória sobre um menino e um elefante imaginário que juntos enfrentavam dificuldades e medos cotidianos da criança. A mensagem por trás da estória era da importância da amizade, apesar das diferenças entre um amigo pequeno e outro grande. O curta participou de diversos festivais, recebendo o prêmio de melhor curta de animação no Festival Internacional de Cine para Niños y Jovenes em 2006.

Ainda em 2006, um canadense veio ao Brasil fazer um workshop sobre animação e os sócios da 2DLab, por meio desse produtor, mantiveram o primeiro contato com o mercado canadense. Para ampliar esse contato, passaram a frequentar feiras como a MIPCOM, junto com outras produtoras brasileiras, com diversos projetos. Entretanto, foi o curta Meu Amigãozão que despertava o interesse das produtoras internacionais. O curta então foi transformado em conceito, cujo pano de fundo era a amizade e questões envolvendo a socialização com foco no público pré-escolar. Foi criada assim a animação de mesmo nome, onde o menino Yuri e seu carinhoso amigo elefante, Golias, ganharam novos amigos: a menina Lili e sua dócil girafa, Nessa, e o hiperativo Matt com seu agitado canguru, Bongo. Juntos os amigos e seus “amigãozões” brincam e se divertem se ajudam mutuamente para enfrentar as dificuldades e os desafios do crescimento. Nas palavras dos criadores da série, “as dificuldades ficam pequenas quando temos grandes amigos”. Cada episódio procura transmitir mensagens conciliadoras e sociáveis. A série mostra como é bom para a criança ter amigos (apesar das diferenças) e, sendo o conceito de amizade universal, ficou fácil vender o projeto para o mercado internacional.

Em 2008 fecharam parceria de coprodução com a Breakthrough do Canadá. Esta trouxe um contrato com a Treehouse, TV canadense reconhecida internacionalmente pela qualidade de sua programação para o público pré-escolar. A parte brasileira conseguiu um contrato com a Discovery Kids, garantindo a distribuição no país, na América Latina e uma possibilidade de exibir a série nos EUA. A animação Meu Amigãozão (My big big friend) foi a primeira série produzida com o Canadá. O orçamento de investimentos da produção recebeu $50 \%$ dos brasileiros e $50 \%$ dos canadenses. A parte brasileira contou com $20 \%$ da verba vinda de contratos com a TV Brasil e a Discovery Kids (que compraram o direito de exibirem 
Um estudo exploratório sobre a indústria brasileira de animação para a TV

primeiro), 40\% de um empréstimo contraído junto ao BNDES (linha ProCult) e os 40\% restantes de incentivos da Lei Rouanet. Da parte canadense, 1/3 foi investido pela TV e a outra parte (2/3) de incentivos fiscais.

A produção iniciou em 2009 e levou 2 anos para ser concluída. No Canadá fizeram o roteiro e o som. A questão do som é muito importante para a distribuição internacional. A primeira voz é gravada em inglês. Partiu-se da ideia que o público brasileiro já estava acostumado a ver animações dubladas. O Meu Amigãozão foi dublado em português e espanhol para a América Latina, além do francês para o Canadá. No Brasil, a equipe da 2DLab ficou responsável pelo storyboard e pela animação. A fase de pós-produção foi em sua maior parte desenvolvida no Canadá.

Só no Brasil, aproximadamente 80 pessoas trabalharam no projeto, sem contar as parcerias firmadas para a parte de finalização (ex.: dublagem) da produção. A estimativa para a $2^{\mathrm{a}}$ temporada, que está em produção, é de utilizar 60 pessoas. Em seu quadro fixo, a 2DLab mantém 15 funcionários, sendo o restante contratado por projeto como o do Meu Amigãozão.

Os brasileiros viajavam constantemente para o Canadá para discutir os roteiros que foram aprovados após cinco revisões. O primeiro episódio levou um ano para ficar pronto e, após a primeira entrega, a cada semana era entregue mais um episódio, em um total de 52 episódios de 11 minutos (o equivalente a 7 longas metragens).

A empresa contou com uma consultoria pedagógica da TV canadense para melhor tratar os conceitos centrais da série. O subtexto da série é estimular a imaginação, resolução de problemas e medos, falando com a criança como criança e, embora seja uma ideia brasileira, o Brasil aparece nas entrelinhas do desenho. Os animais, por exemplo, não remetem a nenhum lugar específico do mundo, assim como as crianças são multiculturais. As estórias foram criadas para que crianças brasileiras e canadenses entendam, apesar de viver em contextos diferentes. Desse modo, estórias com neve e beisebol foram vetadas, credenciando a série brasileira a ser um produto muito mais internacional.

A estreia da primeira temporada de Meu Amigãozão ocorreu no Brasil no canal da TV paga, Discovery Kids em agosto de 2010 (antes da produção da série terminar) e no Canadá em setembro de 2011 pela Treehouse. Atualmente, a série também é exibida pelo canal TV Brasil, na Tailândia, Nova Zelândia, nos EUA pela Discovery Family e Netflix. Com um trabalho de licenciamento sendo administrado pela Kasmanas, a marca é exibida em mais de 100 produtos de 14 empresas como DVDs, brinquedos, álbuns de figurinhas, materiais para 
Wilian Gatti Junior, Marilson Alves Gonçalves (in memoriam) \& Ana Paula Franco Paes Leme Barbosa

festas, papelaria, material escolar, vestuário etc. A produtora criou uma praça temática que circula em shoppings centers para divulgar a série. Como próximos passos, a 2DLab trabalha na produção de um longa-metragem e em uma coleção de DVDs com os episódios da série.

\section{DISCUSSÃO}

Para competir com sucesso no mercado, as produtoras estudadas enfrentaram desafios relacionados à produção, ao mercado e às polaridades relacionadas à própria indústria criativa.

Em todos os casos analisados, o conceito da série surgiu com um insight, mas desde que foi pensada para o mercado de animação, a ideia ganhou contornos globais. Em outras palavras, seria uma animação que pudesse agradar públicos de qualquer cultura. Assim, em nenhuma das produções são identificados com clareza traços culturais distintivos da cultura brasileira, com ressalva a trilha sonora da série Peixonauta, que segundo a produtora, é uma marca registrada e seu ponto de diferenciação.

Dada a importância da fase de Desenvolvimento da produção, pois dela emerge todo o conceito da série, em todos os casos houve intenso envolvimento das empresas e seus respectivos parceiros de coprodução. Nas fases seguintes, conforme a especialidade de cada produtora e o formato acertado de coprodução, observou-se diferenças quanto a responsabilidade por cada etapa. Assim, a Flamma não se envolveu diretamente nas fases de pré-produção, produção e pós-produção. Já a TV Pinguim se envolveu diretamente em todas as fases, o mesmo que a 2DLab, com exceção à fase de pós-produção.

Entretanto, foi o passo imediatamente anterior a todas essas fases do processo produtivo que exigiu mais de cada uma das produtoras. Com a falta de experiência brasileira no mercado de animações, convencer os parceiros a coproduzir uma série e principalmente, investir na ideia, torna os três casos muito especiais, o que reforça a qualidade de cada uma das séries e dos profissionais envolvidos.

A busca de recursos para o financiamento foi sem dúvida um dos momentos críticos de toda a trajetória. De modo distinto, cada produtora obteve recursos para financiar seu projeto. A primeira empresa a buscá-lo foi a Flamma. No início de 2004, ainda sem apoio formal da BTVP, a empresa contou com a experiência anterior de um dos seus sócios e sua rede de relacionamento para firmar um acordo de coprodução com produtoras internacionais, cedendo parte dos direitos de propriedade e sem captar recursos no Brasil. A segunda empresa 
Um estudo exploratório sobre a indústria brasileira de animação para a TV

a buscar recursos foi a TV PinGuim. Quando iniciou seu projeto, a produtora paulista buscava um acordo de coprodução com uma produtora canadense, porém antes mesmo de iniciar a produção, o contrato foi rescindido e um novo foi fechado com o canal de TV Discovery Kids (que utilizou o artigo 39 para se isentar da CONDECINE). Essa nova parceria possibilitou maior autonomia para produtora, além da manutenção dos direitos patrimoniais da sua produção. Ser considerada uma produção 100\% nacional é até hoje bem explorada pela produtora como diferencial. Faltava, porém a empresa a captação dos recursos para finalizar a produção. Inicialmente conseguiram um patrocínio de uma grande indústria de alimentos (beneficiada pela isenção tributária proporcionada pela Lei Rouanet) e o restante do financiamento foi obtido após a criação de uma linha específica do BNDES (Procult), além de recursos próprios. A última empresa a produzir foi a 2DLab. A principio foi a empresa que encontrou o mercado já definido com relação a linhas de financiamento e possibilidades de acordos de coprodução. A presença do Brasil nas feiras do setor já estava consolidada e o país já tinha casos de sucesso para apresentar. Com um cenário um pouco mais favorável, a 2DLab fechou parceria com uma produtora canadense e financiou o restante da produção com recursos do governo. Em termos comparativos, da assinatura do contrato até o início da produção, a Flamma esperou quase dois anos, a TV PinGuim pouco mais de um ano e a 2DLab menos de um ano. Esses prazos sinalizam as dificuldades encontradas pelos pioneiros e o momento positivo do setor.

Uma vez equacionados os problemas de financiamento, faltava às produtoras o desafio de coordenação do projeto de produção e o controle do cronograma, porém, dado o profissionalismo exigido pelos canais de TV, os prazos dos projetos foram alcançados e giraram em torno de 18 a 22 meses. O quadro 2 resume os principais pontos relacionados à gestão do projeto das produtoras.

REAd | Porto Alegre - Edição 78 - Nº 2 - maio/agosto 2014 - p. 461-495 
Wilian Gatti Junior, Marilson Alves Gonçalves (in memoriam) \&

Ana Paula Franco Paes Leme Barbosa

Quadro 2 - Fases e requisitos da produção

\begin{tabular}{|c|c|c|c|}
\hline Aspectos Analisados & Flamma & TV PinGuim & 2DLab \\
\hline $\begin{array}{l}\text { Modelo de produção / } \\
\text { Financiamento }\end{array}$ & $\begin{array}{l}\text { Coprodução com } \\
\text { produtoras internacionais } \\
\text { (Austrália e Espanha) } \\
\text { Investimento australiano } \\
\text { Divisão de territórios } \\
\text { Venda de direitos de } \\
\text { propriedade }\end{array}$ & $\begin{array}{l}\text { Coprodução com canal de } \\
\text { TV no Brasil } \\
\text { Investimento do canal } \\
\text { (isenção fiscal), } \\
\text { patrocínio (Lei Rouanet), } \\
\text { recursos do BNDES } \\
\text { (Procult) e recursos } \\
\text { próprios } \\
\text { Manutenção dos direitos } \\
\text { de propriedade }\end{array}$ & $\begin{array}{l}\text { Coprodução com } \\
\text { produtora internacional } \\
\text { (Canadá). } \\
\text { Investimento do } \\
\text { coprodutor e recursos } \\
\text { públicos (BNDES). } \\
\text { Manutenção dos direitos } \\
\text { de propriedade }\end{array}$ \\
\hline Conceito da série & $\begin{array}{l}\text { Animação pensada para o } \\
\text { mercado internacional } \\
\text { Desenvolvimento } \\
\text { conjunto Flamma e } \\
\text { Southern Star }\end{array}$ & $\begin{array}{l}\text { Animação pensada para o } \\
\text { mercado internacional } \\
\text { Desenvolvimento } \\
\text { conjunto TV PinGuim e } \\
\text { Discovery Kids } \\
\text { Toque brasileiro: trilha } \\
\text { sonora }\end{array}$ & $\begin{array}{l}\text { Animação pensada para o } \\
\text { mercado internacional } \\
\text { Desenvolvimento } \\
\text { conjunto 2DLab e } \\
\text { Breakthrough }\end{array}$ \\
\hline Pré-Produção & Southern Star & TV PinGuim & 2DLab e Breakthrough \\
\hline Produção & Neptuno & TV PinGuim & 2DLab \\
\hline Pós-produção & Neptuno & $\begin{array}{l}\text { TV PinGuim (com } \\
\text { aprovação do Discovery } \\
\text { Kids) }\end{array}$ & Breakthrough \\
\hline Cronograma & $\begin{array}{l}\text { Atendeu aos requisitos do } \\
\text { mercado. Produção em } 18 \\
\text { meses. }\end{array}$ & $\begin{array}{l}\text { Atendeu aos requisitos do } \\
\text { mercado. Produção em } 22 \\
\text { meses. }\end{array}$ & $\begin{array}{l}\text { Atendeu aos requisitos do } \\
\text { mercado. Produção em } 22 \\
\text { meses. }\end{array}$ \\
\hline
\end{tabular}

Fonte: autores deste estudo

O paradigma vigente, construído pela indústria americana, dificultava a exibição de conteúdo produzido no país na TV aberta. Com a introdução dos canais da TV paga no Brasil e a segmentação da programação que emergiu deles (ex.: canais exclusivos para desenhos), abriram-se novas possibilidades para a transmissão da produção nacional. Faltava ao setor a capacidade de financiar e exportar seus projetos, uma vez que uma série produzida para a TV, não consegue se pagar se for exibida apenas para o mercado brasileiro.

Todo esse contexto institucional passou a se alterar a partir de meados dos anos 2000. Observou-se que isoladamente nenhuma produtora poderia alterar esse panorama. Pelo contrário. Quando a escassa produção brasileira de animação deixava de ser produzida para a TV (em geral pública), o empresário do setor migrava para a produção de conteúdo para a publicidade. Esse ciclo não criava nenhuma pressão para que os agentes do setor alterassem as condições do mercado. Apenas com a criação da ABPI-TV, em 1999, e as ações que se 
Um estudo exploratório sobre a indústria brasileira de animação para a TV

seguiram, como por exemplo, a associação com a Apex para a divulgação do conteúdo brasileiro no exterior, é que se fizeram notar as primeiras alterações positivas no mercado. As produções brasileiras passaram a contar com acordos de coprodução, em especial com o Canadá, o que abriu a possibilidade de conquistar novos mercados, uma linha de crédito específica foi criada pelo BNDES e a imprensa passou a noticiar uma série de iniciativas de produtoras nacionais na indústria de animação.

Em resumo, as empresas estudadas conseguiram superar as barreiras de mercado com a convergência de dois importantes fatores. O primeiro decorrente do novo cenário que se formou após a associação das empresas do setor, o que demonstra que os movimentos em bloco são mais relevantes do que ações isoladas. Nesse novo cenário, criaram-se as condições para a produção e exibição de conteúdo, embora as empresas tenham se utilizado dele de maneiras distintas. Como demonstrado, a Flamma não se beneficiou do contexto que emergiu após a criação da BTVP e do Procult, enquanto a TV PinGuim e a 2DLab já fizeram uso desses recursos. Essa vantagem que TV PinGuim e 2DLab tiveram se materializou com o direito de propriedade. O segundo fator diz respeito às competências das produtoras na produção de conteúdo para o público pré-escolar. Essa competência, adquirida por meio da experiência prática de vários anos, tanto de gestão quanto de produção de conteúdo cultural e audiovisual, resultou na construção de uma boa animação, que conta com fluidez de movimentos, riqueza de elementos visuais e uso da imaginação para transmitir valores e contar boas estórias.

Os números demonstram que as produtoras obtiveram êxito no mercado. Há mais tempo na TV, a produção da Flamma é exibida em pouco mais de 100 países; aliás, diferentemente das demais, Princesas do Mar estreou primeiro no mercado internacional e depois no Brasil. A série da TV PinGuim segue o mesmo caminho e já está em mais de 60 territórios. A 2DLab está no começo, mas também já está com seu produto no exterior. O mesmo é válido para o licenciamento de produtos, onde todos já licenciaram suas marcas para o mercado brasileiro, por meio de parcerias firmadas com empresas especializadas. O quadro 3 resume os principais resultados mercadológicos envolvendo as produtoras estudadas. 
Wilian Gatti Junior, Marilson Alves Gonçalves (in memoriam) \&

Ana Paula Franco Paes Leme Barbosa

Quadro 3 - Resultados mercadológicos

\begin{tabular}{|c|c|c|c|}
\hline Aspectos Analisados & Flamma & TV PinGuim & 2DLab \\
\hline \multirow[t]{2}{*}{ Exibição no Brasil } & $\begin{array}{l}\text { Estreia em mar/2008 na } \\
\text { Discovery Kids }\end{array}$ & $\begin{array}{l}\text { Estreia em abr/2009 na } \\
\text { Discovery Kids }\end{array}$ & $\begin{array}{l}\text { Estreia em ago/2010 na } \\
\text { Discovery Kids }\end{array}$ \\
\hline & TV aberta: TV Cultura & TV aberta: SBT & TV aberta: TV Brasil \\
\hline \multirow[t]{3}{*}{ Exibição no Exterior } & $\begin{array}{l}\text { Estreia na Austrália em } \\
\text { set/2007 }\end{array}$ & $\begin{array}{l}\text { Série está hoje em } 67 \\
\text { países }\end{array}$ & $\begin{array}{l}\text { Estreia no Canadá em } \\
\text { set/2011 }\end{array}$ \\
\hline & $\begin{array}{l}\text { Série está hoje em } 126 \\
\text { países }\end{array}$ & $\begin{array}{l}\text { Distribuição: } \\
\text { Breakthrough }\end{array}$ & $\begin{array}{l}\text { Série está hoje no } \\
\text { Canadá, Tailândia, Nova } \\
\text { Zelândia e EUA }\end{array}$ \\
\hline & Star & & $\begin{array}{l}\text { Distribuição: } \\
\text { Breakthrough }\end{array}$ \\
\hline \multirow[t]{2}{*}{ Licenciamento } & Parceiro: Kasmanas & Parceiro: Redibra & Parceiro: Kasmanas \\
\hline & $\begin{array}{l}\text { Está presente em } 190 \\
\text { produtos }\end{array}$ & $\begin{array}{l}\text { Está presente em } 300 \\
\text { produtos }\end{array}$ & $\begin{array}{l}\text { Está presente em } 100 \\
\text { produtos }\end{array}$ \\
\hline \multirow[t]{2}{*}{$\begin{array}{l}\text { Outros produtos baseados } \\
\text { na série }\end{array}$} & Não estão previstos & $\begin{array}{l}\text { Em cartaz uma peça de } \\
\text { teatro }\end{array}$ & $\begin{array}{l}\text { Praça temática em } \\
\text { shopping centers }\end{array}$ \\
\hline & & $\begin{array}{l}\text { Em produção: um longa } \\
\text { metragem 3D e um DVD } \\
\text { musical }\end{array}$ & $\begin{array}{l}\text { Em estudo: um longa } \\
\text { metragem e uma coleção } \\
\text { de DVDs }\end{array}$ \\
\hline
\end{tabular}

Fonte: autores deste estudo

Os últimos desafios de gestão, identificados nas empresas estudadas, dizem respeito à natureza da indústria criativa, mais especificamente as polaridades identificadas por Lampel, Lant e Shamsie (2000). A primeira delas é conciliar os valores artísticos da produção com o valor de mercado. Nesse ponto, as três empresas atuaram de forma pragmática. A criatividade se restringiu ao desenvolvimento dos personagens e o enredo dos episódios. O contexto das séries foi todo pensado para atender ao mercado, principalmente o internacional. Assim, as produtoras equacionaram a pressão entre os dois fatores, com predominância dos valores de mercado em detrimento ao conteúdo artístico das séries. Esse tópico está diretamente ligado a pressão pela inovação versus a diferenciação do produto. Aqui as três empresas estudadas não produziram uma inovação. As produtoras seguiram a fórmula narrativa hoje empregada na TV. A diferenciação, resultante do seu processo criativo, ocorreu, como já mencionado, nos personagens e nas estórias contadas, mas todo o resto ficou submetido ao sistema hoje vigente na TV mundial.

A análise da demanda em contraste com a construção do mercado não é exatamente um dilema gerencial para estúdios do porte dos estudados. Claramente, a Pixar, com o lançamento de “Toy Story” moldou a preferência por um novo tipo de animação forçando o 
Um estudo exploratório sobre a indústria brasileira de animação para a TV

restante da indústria do cinema a se adaptar a um novo padrão de qualidade. Não é o caso dos estúdios nacionais. Eles partiram do estudo e discussão sobre as preferências do público préescolar (a 2DLab até contou com assessoria de uma psicóloga infantil) para o desenvolvimento de suas séries. No segmento de TV, são os canais que moldam o gosto do público e os estúdios que querem vender sua produção devem se adaptar ao modelo vigente.

As decisões envolvendo a integração vertical ou a especialização flexível também não preocuparam os executivos entrevistados. A integração vertical é um modelo adotado pelos grandes estúdios americanos de cinema que controlam a produção, distribuição e licenciamento dos produtos. As empresas estudadas apresentaram pequenas diferenças nesse sentido. A Flamma é a mais especializada não possuindo sequer um estúdio de animação. A TV PinGuim e 2DLab, há muito mais tempo no mercado, ao contrário, operaram com um nível maior de integração por contar com animadores em seus quadros. Essas decisões envolvem naturalmente custos de mão de obra, mas possibilitam um maior controle sobre o processo produtivo. As atividades que não eram competência das produtoras foram terceirizadas, como a distribuição internacional e licenciamento.

A última polaridade observada questiona se a capacidade individual é o centro do processo criativo na cadeia de valor ou se é o sistema como um todo que alimenta o sucesso de produtos criativos. No contexto brasileiro, que ainda está no estágio de formação de uma indústria voltada para a animação, o empreendedorismo individual se sobressai sobre o sistema no que se refere ao processo criativo. Em outras palavras, não há um ambiente institucional que impulsione a inovação como, por exemplo, se observa nos EUA em Hollywood para a indústria do audiovisual ou no Vale do Silício para a indústria de tecnologia. O sistema ou a cadeia de valor foi responsável pelos mecanismos para financiamento, produção e exibição de conteúdo - sem ele as ideias criativas ficariam no meio do caminho. Porém, ainda no estágio em que se encontra o Brasil, são os indivíduos que movem a indústria. As dificuldades encontradas pela Flamma, a primeira a se lançar no mercado, demonstram isso. Das empresas analisadas foi a única que cedeu seus direitos de propriedade para viabilizar a produção. Em um ambiente como o encontrado pela 2DLab, provavelmente isso não ocorreria. A busca de uma fonte de recursos pelos sócios da TV PinGuim, antes de obter recursos do Procult, é outro exemplo, que serve para ilustrar a força empreendedora, comprovando a prevalência do individual em relação ao sistema. A união de uma ideia criativa e um perfil empreendedor, com um sistema que financia essas ideias e as 
Wilian Gatti Junior, Marilson Alves Gonçalves (in memoriam) \&

Ana Paula Franco Paes Leme Barbosa

levam a um estágio de produção foram essenciais em todas as empresas estudadas. Porém, o ambiente ainda não fomenta a criatividade.

O quadro 4 resume como cada uma das empresas estudadas gerenciou as polaridades estudadas.

Quadro 4 - Gerenciamento das polaridades

\begin{tabular}{|c|c|c|c|}
\hline Aspectos Analisados & Flamma & TV PinGuim & 2DLab \\
\hline $\begin{array}{c}\text { Valores artísticos } \mathrm{x} \\
\text { Entretenimento de massa }\end{array}$ & $\begin{array}{l}\text { Desenvolveu um produto } \\
\text { pensando no mercado } \\
\text { (internacional) }\end{array}$ & $\begin{array}{l}\text { Desenvolveu um produto } \\
\text { pensando no mercado } \\
\text { (internacional) }\end{array}$ & $\begin{array}{l}\text { Desenvolveu um produto } \\
\text { pensando no mercado } \\
\text { (internacional) }\end{array}$ \\
\hline $\begin{array}{c}\text { Diferenciação de } \\
\text { produtos x Inovação de } \\
\text { mercado }\end{array}$ & $\begin{array}{l}\text { Produto similar aos } \\
\text { exibidos pela TV }\end{array}$ & $\begin{array}{l}\text { Produto similar aos } \\
\text { exibidos pela TV }\end{array}$ & $\begin{array}{l}\text { Produto similar aos } \\
\text { exibidos pela TV }\end{array}$ \\
\hline $\begin{array}{l}\text { Análise da demanda x } \\
\text { Construção do mercado }\end{array}$ & $\begin{array}{l}\text { Partiu da análise do } \\
\text { mercado para desenvolver } \\
\text { sua animação }\end{array}$ & $\begin{array}{l}\text { Partiu da análise do } \\
\text { mercado para desenvolver } \\
\text { sua animação }\end{array}$ & $\begin{array}{l}\text { Partiu da análise do } \\
\text { mercado para desenvolver } \\
\text { sua animação }\end{array}$ \\
\hline $\begin{array}{c}\text { Integração vertical x } \\
\text { Especialização flexível }\end{array}$ & $\begin{array}{l}\text { Empresa se concentrou na } \\
\text { coordenação do projeto }\end{array}$ & $\begin{array}{l}\text { Nível de integração baixo. } \\
\text { Apenas da parte de } \\
\text { produção da animação }\end{array}$ & $\begin{array}{l}\text { Nível de integração baixo. } \\
\text { Apenas da parte de } \\
\text { produção da animação }\end{array}$ \\
\hline $\begin{array}{l}\text { Inspiração individual x } \\
\text { Sistemas criativos }\end{array}$ & $\begin{array}{l}\text { Criatividade individual e } \\
\text { empreendedorismo } \\
\text { moldaram a criação da } \\
\text { série. Não havia um } \\
\text { sistema de apoio a } \\
\text { produção de animações }\end{array}$ & $\begin{array}{l}\text { Criatividade individual e } \\
\text { empreendedorismo } \\
\text { moldaram a criação da } \\
\text { série. Início de um } \\
\text { sistema institucional para } \\
\text { apoiar a produção }\end{array}$ & $\begin{array}{l}\text { Criatividade individual e } \\
\text { empreendedorismo } \\
\text { moldaram a criação da } \\
\text { série. Encontraram um } \\
\text { sistema institucional para } \\
\text { apoiar a produção }\end{array}$ \\
\hline
\end{tabular}

Fonte: autores deste estudo

\section{CONSIDERAÇÕES FINAIS}

O objetivo dessa pesquisa foi entender como produtoras nacionais da indústria de animação conseguiram produzir e exibir suas produções num mercado historicamente dominado por estúdios internacionais. Para isso, buscou entender como esses pequenos estúdios brasileiros construíram vantagens competitivas que permitiram sua sobrevivência nesse contexto.

O trabalho revelou a convergência de duas fontes de vantagem competitiva. A primeira ligados a fatores internos às produtoras estudadas (conhecimento técnico e visão do negócio/mercado) e a segunda fonte ligada a fatores ambientais, criados pela cadeia produtiva dessa indústria (criação de novos canais de TV, interesse de parceiros internacionais e linhas de financiamento para a produção). 
Um estudo exploratório sobre a indústria brasileira de animação para a TV

No que se refere aos recursos internos das produtoras estudadas, este trabalho revelou com destaque o conhecimento acumulado pelos sócios das produtoras ao longo de vários anos atuando na indústria criativa. Essa experiência, que se traduziu no comprometimento (paixão) pelo seu produto, aliada a visão de negócio e do mercado, foi decisiva para tornar o conceito das séries em produtos de sucesso na TV. Essa experiência contribuiu também para o desenvolvimento de animações com valores universais e interessantes ao grande público, ao mesmo tempo em que foi utilizada para a formatação dos acordos de coprodução e na busca de financiamento. Essas evidências confirmar as observações de Barney (1997) relativas as condições históricas únicas do desenvolvimento dos recursos e das competências da organização para a construção da vantagem competitiva.

Diferentemente do que se podia imaginar, os criadores das séries não se restringiram a criação das estórias e personagens, mas utilizaram competências gerenciais para superar polaridades, integrar processos de desenvolvimento com parceiros de negócio, organizar equipes multifuncionais de trabalho espalhadas geograficamente e habilidades para reunir o pragmatismo para atender a cronogramas e orçamento com a criatividade exigida para a criação de estórias interessantes.

No que tange a formação da vantagem competitiva sob a ótica ambiental, o contexto de negócios formado pelos agentes dessa cadeia produtiva, após a introdução das TVs pagas no Brasil, favoreceu a produção de animações no país aumentando a atratividade do setor (PORTER, 1986). Canais dedicados a desenhos aumentaram a demanda por animações e o setor iniciou um movimento articulado, que culminou na criação de uma associação com clara intenção de promover e exportar a produção nacional. Além disso, a exemplo de produtoras de outros países, as produtoras nacionais foram buscar recursos que começaram a surgir após 2001 para financiar a indústria no país, principalmente a linha Procult do BNDES.

A importância dessas conquistas pode ser comprovada pela formatação dos acordos de direitos patrimoniais das animações estudadas. Notou-se claramente que a pioneira Flamma, sem o suporte de linhas de financiamento, teve que ceder boa parte dos seus direitos para produtoras internacionais para captar recursos para a sua produção. A TV PinGuim, que trabalhava com o Peixonauta, em um momento de transição conseguiu manter seus direitos, mas percorreu um longo caminho até obter o investimento necessário. Já em um período posterior, em um ambiente um pouco mais estável, a 2DLab obteve os recursos para cobrir seu orçamento. Embora tenham viabilizado suas produções em momentos e condições 
Wilian Gatti Junior, Marilson Alves Gonçalves (in memoriam) \&

Ana Paula Franco Paes Leme Barbosa

distintas, a coprodução foi o modelo adotado por todas, sugerindo um padrão para o desenvolvimento de animações para as produtoras nacionais nos próximos anos. A coprodução assim desenvolve dois importantes papéis: ajuda a viabilizar a produção com a captação de recursos no exterior (mantendo os direitos patrimoniais no país), além de ser uma forma que as produtoras nacionais tem para aprender com os grandes centros produtores de animação.

Duas contribuições desta pesquisa podem assim ser destacadas. A primeira ligada aos trabalhos que buscam identificar os fatores que levam a construção de vantagens competitivas. A pesquisa pode avançar em estudos em pequenas empresas num setor muito pouco estudado e identificou que, no ambiente pesquisado, não bastam os fatores internos como os que puderam ser identificados (o que poderia se imaginar a priori em indústrias criativas dada a natureza de sua atividade), mas a integração destes com os fatores externos (ligados ao governo e principalmente parceiros de negócio) são por vezes determinantes para o desenvolvimento e sucesso e a construção de uma vantagem competitiva.

A segunda contribuição é o setor foco da pesquisa. O trabalho apresentou ainda não explorado pela literatura, mostrando que o Brasil está criando uma indústria e se posicionando no mercado internacional de animações para a TV. Entretanto, deve-se reconhecer que, para o país de fato ser reconhecido como produtor de conteúdo, incluindo o desenvolvimento do roteiro, a concepção dos storyboards e de todas as etapas da animação, incluindo trabalho de voz, trilha sonora etc., é preciso mais experiências de sucesso como as que foram apresentadas.

Diversas são as possibilidades de pesquisas nesse setor. Bendassolli et al. (2009) dão pistas do que pode ser adaptado à indústria de animação. Destacam-se aqui quatro temas. Primeiro, a análise da gestão das indústrias do setor, pois desafios entre o trabalho artístico e as exigências do mercado precisam ser equacionados e como relacionar essa gestão com as práticas empresariais “tradicionais". Segundo, alguns trabalhos poderiam estudar a organização do trabalho no ambiente da produtora, com destaque ao processo de produção de animações, analisando o trabalho individual versus o trabalho em equipe e a aplicação de princípios de gestão de operações nesse contexto. Uma terceira linha de pesquisa poderia se concentrar no papel do governo no incentivo e financiamento de produções de animações, tanto para a criação de uma indústria de fato, como para fomentar um setor, que a exemplo do que ocorre nos EUA, gera divisas além de divulgar a cultura do país. Finalmente, com os 
Um estudo exploratório sobre a indústria brasileira de animação para a TV

sinais evidentes identificados pelo presente trabalho, o início de um processo de desenvolvimento da indústria de animação no Brasil, abre-se espaço para discussão e estudo das cadeias produtivas desta indústria e a inserção das produtoras nacionais em redes globais de produção.

Em particular, nos próximos anos, sediando eventos esportivos de âmbito mundial, o Brasil pode oferecer um ambiente nutritivo para pesquisa neste campo. Sob a ótica da Teoria dos Custos de Transação, da Teoria da Agência, da Teoria da Visão Baseada em Recursos, da Teoria da Dependência de Recursos e da Teoria Institucional surgem perspectivas interessantes de entendimento de tendências de verticalização e horizontalização das cadeias produtivas de animação para a TV e cinema, além de outros segmentos da indústria criativa.

\section{REFERÊNCIAS}

ALVES-MAZZOTI, A. J.; GEWANDSZNAJDER, F. O método nas ciências naturais e sociais: pesquisa quantitativa e qualitativa. São Paulo: Pioneira Thomson Learning, 2001.

ANSOFF, H.I. Corporate Strategy. Hamondsworth: Penguin, 1965.

AGÊNCIA NACIONAL DO CINEMA (ANCINE). Rio de Janeiro, 2011. Disponível em: $<$ http://www.ancine.gov.br>. Acesso em: 19/11/2011.

BARNEY, J. Firm resources and sustained competitive advantage. Journal of Management, v.17, n.1, p.99-120, 1991.

BARNEY, J. Gaining and sustaining competitive advantage. Reading, MA: AddisonWestey Publishing Company, 1997.

BENDASSOLLI, P. F.; WOOD JR., T.; KIRSCHBAUM, C.; CUNHA. M. P. Indústrias criativas: definição, limites e possibilidades. Revista de Administração de Empresas, São Paulo, v. 49, n. 1, 2009.

BNDES. Programa BNDES para o Desenvolvimento da Economia da Cultura - BNDES Procult. Disponível em:

<http://www.bndes.gov.br/SiteBNDES/bndes/bndes_pt/Areas_de_Atuacao/Cultura/Procult//> . Acesso: 26/05/2013. 
Wilian Gatti Junior, Marilson Alves Gonçalves (in memoriam) \& Ana Paula Franco Paes Leme Barbosa

BRASIL. Economia criativa cresce no Brasil, diz relatório da ONU. Brasília, 07/11/2011. Disponível em: <http://www.brasil.gov.br/noticias/arquivos/2011/11/07/economia-criativacresce-no-brasil-diz-relatorio-da-onu/view>. Acesso: 20/11/2011.

BRASIL. Lei no 8.313/91, de 23 de dezembro de 1991. Restabelece princípios da Lei ${ }^{\circ}$ 7.505, de 2 de julho de 1986, institui o Programa Nacional de Apoio à Cultura (Pronac) e dá outras providências. Diário Oficial [da] República Federativa do Brasil, Poder Executivo, Brasília, DF, 24 dez. 1991. Seção 1, p. 30261.

BRASIL. Lei no 8.685/93, de 20 de julho de 1993. Cria mecanismos de fomento à atividade audiovisual e dá outras providências. Diário Oficial [da] República Federativa do Brasil, Poder Executivo, Brasília, DF, 21 jul. 1993. Seção 1, p. 10107.

BRASIL. Lei $n^{\circ}$ 12.485/11, de 12 de setembro de 2011. Dispõe sobre a comunicação audiovisual de acesso condicionado; altera a Medida Provisória $\mathrm{n}^{0}$ 2.228-1, de 6 de setembro de 2001, e as Leis nos 11.437, de 28 de dezembro de 2006, 5.070, de 7 de julho de 1966, 8.977, de 6 de janeiro de 1995, e 9.472, de 16 de julho de 1997; e dá outras providências.

Diário Oficial [da] República Federativa do Brasil, Poder Executivo, Brasília, DF, 13 set. 2011. Seção 1, p. 2.

BRASIL. Medida Provisória n 2.281/01, de 6 de setembro de 2001. Estabelece princípios gerais da Política Nacional do Cinema, cria o Conselho Superior do Cinema e a Agência Nacional do Cinema - ANCINE, institui o Programa de Apoio ao Desenvolvimento do Cinema Nacional - PRODECINE, autoriza a criação de Fundos de Financiamento da Indústria Cinematográfica Nacional - FUNCINES, altera a legislação sobre a Contribuição para o Desenvolvimento da Indústria Cinematográfica Nacional e dá outras providências. Diário Oficial [da] República Federativa do Brasil, Poder Executivo, Brasília, DF, 10 set. 2001. Seção 1, p. 3.

CALDEIRA, J. B. Avant-première. Disponível em:

<http://www.valor.com.br/cultura/1027394/avant-premiere>. Acesso: 11/11/2011.

DALMAZO, L. Um novo produto de exportação. Exame, São Paulo: Abril, ed. 0949, ano 43, n. $15,12 / 08 / 2009$.

DENKER, A. F. M.; VIÁ, S. C. Pesquisa empírica em ciências humanas: com ênfase em comunicação. 2. ed. São Paulo: Futura, 2001.

EISENHARDT, K. M. Building Theories from Case Study Research. Academy of Management Review, v.14, n.4, p.532-550, 1989.

REAd | Porto Alegre - Edição 78 - Nº 2 - maio/agosto 2014 - p. 461-495 
Um estudo exploratório sobre a indústria brasileira de animação para a TV

EISENHARDT, K. M.; MARTIN, J. A. Dynamic capabilities: what are they? Strategic Management Journal, v. 21, n. 10-11, p. 1105-1121, out 2000.

FERNANDES, L. A.; GOMES, J. M. M. Relatórios de pesquisa nas ciências sociais: características e modalidades de investigação. Contexto, Porto Alegre, v. 1, p. 71-92, 2003

GIBBS, G. Análise de dados qualitativos. Porto Alegre: Artmed, 2009.

GODOY, A. S. Introdução à pesquisa qualitativa e suas possibilidades. Revista de Administração de Empresas, São Paulo, v. 35, n. 2, p. 57-63, mar./abr.1995.

LAMPEL J.; LANT T.; SHAMSIE J. Balancing act: Learning from organizing practices in cultural industries. Organization Science, v. 11, n. 3, p. 263-269, 2000.

McCUTCHEON, D. M.; MEREDITH, J. R. Conducting case study research in operations management. Journal of Operations Management, v. 11, p. 239-256, 1993.

MILES, M. B.; HUBERMAN, A. M. Qualitative data analysis: an expanded sourcebook. 2. ed. London: Sage, 1994.

MINTZBERG, H.; AHLSTRAND, B.; LAMPEL, J. Safári de estratégia: um roteiro pela selva do planejamento estratégico. 2. ed. Porto Alegre: Bookman, 2010.

NEVES, J. L. Pesquisa Qualitativa: características, usos e possibilidades. Caderno de Pesquisas em Administração, São Paulo, v.1, n. 3, 1996.

PORTER, M. E. Estratégia Competitiva: técnicas para análise de indústrias e da concorrência. 7. ed. Rio de Janeiro: Elsevier, 1986.

PORTER, M.E. Towards a dynamic theory of strategy. Strategic Management Journal, v.12, p.95-117, Winter, 1991.

RAUGUST, K. The animation business handbook. New York: St. Martins Press, 2004. 
Wilian Gatti Junior, Marilson Alves Gonçalves (in memoriam) \& Ana Paula Franco Paes Leme Barbosa

SELLTIZ, C.; JAHODA, M.; DEUTSCH, M.; COOK, S. W. Métodos de pesquisa nas relações sociais. São Paulo: EDUSP, 1975.

TSCHANG, T.; GOLDSTEIN, A. Production and political economy in the animation industry: why insourcing and outsourcing occur. In: DRUID Summer Conference, 2004, Elsinore, Dinamarca. Proceedings...Elsinore, 2004.

TV BRASIL. Revista do Cinema Brasileiro. Rio de Janeiro, 2011. Disponível em: $<$ http://revistadocinemabrasileiro.com.br/node/1292>. Acesso: 11/11/2011.

VASCONCELOS, F. C.; CYRINO, A. B. Vantagem Competitiva: os modelos teóricos atuais e a convergência entre estratégia e teoria organizacional. RAE - Revista de Administração de Empresas, v.40, n.4, p.20-37. São Paulo: Out./Dez., 2000.

WINDER, C.; DOWLATABADI, Z. Producing animation. Burlington: Focal Press, 2001.

YIN, R. K. Estudo de caso: planejamento e métodos. 3. ed. Porto Alegre: Bookman, 2005.

YOON, H. The animation industry: technological changes, production challenges, and global shifts. Columbus, 2008. 162f. Tese (Doutorado em Geografia) - Programa de PósGraduação em Geografia da Ohio State University, Columbus, 2008.

YOON, H.; MALECKI, E. J. Cartoon planet: worlds of production and global production network in the animation industry. Industrial and Corporate Change, v. 19, n. 1, p. 239271, 2009. 